\title{
Cabrera's Vole Microtus cabrerae Thomas, 1906 and the subgenus Iberomys during the Quaternary: Evolutionary implications and conservation ${ }^{\S}$
}

\author{
José Antonio Garrido-García*, Ramón C. Soriguer-Escofet \\ Estación Biológica de Doñana, Consejo Superior de Investigaciones Científicas (CSIC), Avda. Americo Vespuccio s/n, 41092, Sevilla, Spain
}

Keywords:

Iberomys

Microtus cabrerae

Pleistocene

Holocene

Biogeography

Conservation

\begin{abstract}
A B S T R A C T
The corological evolution of the species of the subgenus Iberomys and, specifically, of Microtus cabrerae, are described. Iberomys appeared in the Iberian Peninsula during the Lower Pleistocene and then reached southern France and Italy during the Middle Pleistocene. M. cabrerae established itself as an Iberian endemic during the final glacial period and subsequently occupied South-Eastern France. This latter population and those found along the Mediterranean coast survived until the Subatlantic period. Thus, it is concluded that Iberomys is endemic to the European sector of the western Mediterranean Basin, but once was found over much more of the Iberian Peninsula, Italy and France. The Iberian Peninsula is, nevertheless, fundamental in its life history as its evolutionary centre and the origin of expansions into other areas. On the other hand, it is possible to locate the centre of origin of the subgenus Iberomys at a regional scale (the Iberian Peninsula) and adapt its evolutionary cycle to a Symmetrical Model. The contraction of the range of M. cabrerae during the Holocene is not related to the Subboreal climatic crisis; rather, it took place during the Subatlantic and could be related to the expansion of agriculture, which probably destroyed many of its habitats. Thus, this reduction in its range is anthropic in origin and could be corrected by means of appropriate management and conservation policies.
\end{abstract}

\section{Introduction}

The appearance during the Pleistocene of refugia and speciation centres in the Mediterranean peninsulas, as well as the expansion into central and northern Europe during the Holocene of taxa originating from these areas, is one of the main factors that has contributed to the configuration of Europe's extant biota (Blondel and Aronson, 1999). To date, the study via phylogeography or through palaeontological and archaeozoological registers, has centred on taxa from the North-West and centre of the continent, while the Mediterranean peninsulas have generally been considered as homogenous units and not as complex systems with localscale refugia (Taberlet et al., 1998; Sommer and Benecke, 2004, 2005, 2008). In the Iberian Peninsula this idea is being revised due to studies that are revealing its internal phylogeographical complexity (Gómez and Lundt, 2007). Even so, and aside from regional scale studies (Garrido-García, 2008), similar progress has not yet been made in the analysis of palaeontological and archaeozoological records.

M. cabrerae is endemic to the Iberian Peninsula and is unique amongst the genus Microtus (monogamy, K-type reproductive

\footnotetext{
\$ Corresponding editor: Gilles Escarguel.

* Corresponding author.

E-mail address: j.agarrido@terra.es (J.A. Garrido-García).
}

strategy, giant $\mathrm{X}$ and $\mathrm{Y}$ chromosomes with multiple copies of the gene SRY; Bullejos et al., 1997; Ventura et al., 1998; Mitchell-Jones et al., 1999; Fernández-Salvador et al., 2001). Moreover, phylogenetic studies (Jaarola et al., 2004) have revealed its taxonomic isolation from the other Palearctic Microtus. This has led this species to be placed in a separate subgenus (Iberomys Chaline, 1974), which is sometimes even considered as a separate genus from Microtus (Laplana and Cuenca-Bescós, 1998). The palaeontological record indicates that subgenus Iberomys evolved along an anagenetic line composed of Microtus huescarensis Mazo et al., 1985, M. brecciensis Giebel, 1874, and M. cabrerae (Cuenca-Bescós et al., 2010). Today, it is one of the most threatened of all European rodents, classified as Near Threatened on a world scale (Fernandes et al., 2008), extinct in France (Pascal et al., 2006) and vulnerable to extinction in Portugal and Spain (Alves et al., 2006; FernándezSalvador, 2007). In some Spanish regions (e.g., Andalusia) it is critically endangered (Garrido-García et al., 2008).

Our aim in this paper is to analyse the biogeographical evolution of $\mathrm{M}$. cabrerae during the Pleistocene and Holocene, and to provide information comparable to that which is available for other European mammals (Sommer and Benecke, 2004, 2005, 2008), thereby contributing to the knowledge of biogeographical changes occurring in Europe during these epochs. Moreover, our intention is to review two fundamental questions regarding the evolution and origin of the current conservation situation of $\mathrm{M}$. cabrerae. First, the evolutionary process in the subgenus Iberomys 
has been used as a case-study in general analyses of the location of the centre of origin and the spatio-temporal evolution of fossil lineages (López Martínez, 2003, 2009). Second, López Martínez (2003) suggested that current problems regarding the conservation of this species are due to the increased aridity of the Iberian Peninsula since the Subboreal period, which has probably led to the loss of numerous populations in southern and eastern Spain and intensely fragmented the remaining ones. Nevertheless, the data used in these studies originates from outdated reviews (Ayarzagüena and López Martínez, 1976) and so it is vital to determine whether these conclusions can be maintained if the findings of the last 35 years are integrated into the analysis.

\section{Material and methods}

\subsection{Collect and classification of data}

Archaeozoological and palaeontological studies conducted in western Europe were reviewed for references to the presence of M. cabrerae, M. brecciensis and M. huescarensis. Data interpretation was often complicated by the use of synonyms since:

- Populations from SE Iberian Peninsula were once considered to belong to a separate species (Microtus dentatus Miller, 1910), which, although rendered invalid (Ayarzagüena and López Martínez, 1976), is still used in some recent studies (Bon et al., 1991);

- It has been proposed that all members of the subgenus Iberomys should be considered as a single species (M. brecciensis) (Delgado Castilla et al., 1993; Ruiz Bustos, 2000);

- Subgenus Iberomys is considered as a separate genus from Microtus, and "I. brecciensis" and "I. cabrerae" are used by LópezGarcía (2008).

All collated records were assigned to one of these three species, taking as a standard the biochronology suggested by CuencaBescós et al. (2010), who assign M. huescarensis to the end of the Lower Pleistocene (900-700 KyBP), M. brecciensis to the Middle Pleistocene and first half of the Upper Pleistocene (700-90 kyBP), and M. cabrerae to the second half of the Upper Pleistocene and the Holocene (90-0 kyBP). As well, records of M. cabrerae were placed in "'Operational Chronological Units" (OCU) which correspond to the climatic phases of the Upper Pleistocene and Holocene (Vernet, 1997; Semah and Renault-Miskovsky, 2004). Given that for many fossil deposits datings are indirectly based on industrial and ceramic remains, we can relate these paleoclimatic periods with the cultural phases of South-West Europe (Dennell, 1999; Riser, 1999; Otte, 2002) and thus generate these OCUs (Table 1).

These OCUs resemble those used by Sommer and Benecke (2004), although the complexity of the Iberian Mesolithic period (Montes Ramírez, 2007) obliged us to group the Preboreal and Boreal periods in the same OCU. Likewise, the Subatlantic was also considered as a single phase since the lack of data meant that any subdivision would have been inadequate. On the other hand, it was possible to distinguish between the Atlantic and Subboreal periods due to the clear archaeological differences present in the study area (neolithic-argaric cultures vs. Bronze age cultures; Otte, 2002).

\subsection{Mapping}

The geographical location of all the sites with presence of the subgenus Iberomys were determined using either bibliographical records or, whenever such records were doubtful or absent, maps (Ministerio de Defensa, 1997 for Spain, and Google Maps for the rest of Europe). The locations obtained were transformed into coordinates of UTM Zone 30 of the European Datum 1950 to a resolution of $1 \mathrm{~m}$. For the distribution maps, UTM $50 \times 50 \mathrm{~km}$ grid squares were considered to be the most appropriate resolution for mapping animal species at continental scale (Mitchell-Jones et al., 1999). An Access database was created in which all $50 \times 50 \mathrm{~km}$ squares with records of the subgenus Iberomys species were entered using the UTM $1 \times 1 \mathrm{~m}$ coordinates of each square's central point. For each square the presence/absence of $M$. huescarensis, M. brecciensis and M. cabrerae were indicated, and for the latter species each occurrence was also associated to an OCU. For each species or OCU a map was generated using the database and a GIS created with ArcGIS 9 on which, in addition, the current distribution of M. cabrerae was shown for comparative purposes (MitchellJones et al., 1999, updated with Fernández-Salvador, 2007; Garrido-García et al., 2008).

\subsection{Analysis of the corological evolution of subgenus Iberomys}

These maps were used as a base for others in which the mapping unit consisted of the sectors created by dividing the zones within the UTM squares into four subzones (NW, NE, SW and SE). The UTM subzones formerly occupied by $M$. huescarensis, M. brecciensis and currently inhabited by $M$. cabrerae in each OCU were counted to create a graph showing the evolution of the size of the distribution area of subgenus Iberomys throughout its history. For the OCUs of M. cabrerae, we began with a hypothesis whereby this rodent has always inhabited its current range, and then added for each period the inhabited area as indicated by the remains found in fossil deposits.

\section{Results}

3.1. General characterization of the biogeographical history of $\mathrm{M}$. cabrerae and the other species of the subgenus Iberomys

Data on subgenus Iberomys exists from 101 archaeological and palaeontological sites located in 69 UTM $50 \times 50 \mathrm{~km}$ squares (Table S1). Of these, at four sites and in four UTM $50 \times 50 \mathrm{~km}$ squares remains of $\mathrm{M}$. huescarensis have been registered, at 51 and in $42 \mathrm{M}$. brecciensis has been found, and at 53 and in $38 \mathrm{M}$. cabrerae has been cited. This latter taxon has been found in 22 squares and 15 sites from the Lower Wü rm, 11/10 from the Upper Wü rm, 9/8 from the Preboreal-Boreal, 19/19 from the Atlantic, 9/9 from the Subboreal and 7/7 from the Subatlantic.

Table 1

“'Operational Chronological Units”, (OCU) defined for the Upper Pleistocene and Holocene.

\begin{tabular}{|c|c|c|}
\hline OCU & Date (BP) & Archaeologic phase \\
\hline Early Würm & $90.0-15.0$ & Mousterian, Aurignacean, Solutrean \\
\hline Recent Würm & $15.0-10.2$ & Magdalenian, Azilian \\
\hline Preboreal-Boreal & $10.2-7.5$ & Mesolithic \\
\hline Atlantic & $7.5-4.5$ & Neolithic, Cardial, Epicardial, Argaric culture \\
\hline Subboreal & $4.5-2.8$ & Bronze Age, Campaniforme, Los Millares and Palmela cultures \\
\hline Subatlantic & $2.8-0.0$ & Iron Age, iberic, roman and Middle Age cultures \\
\hline
\end{tabular}



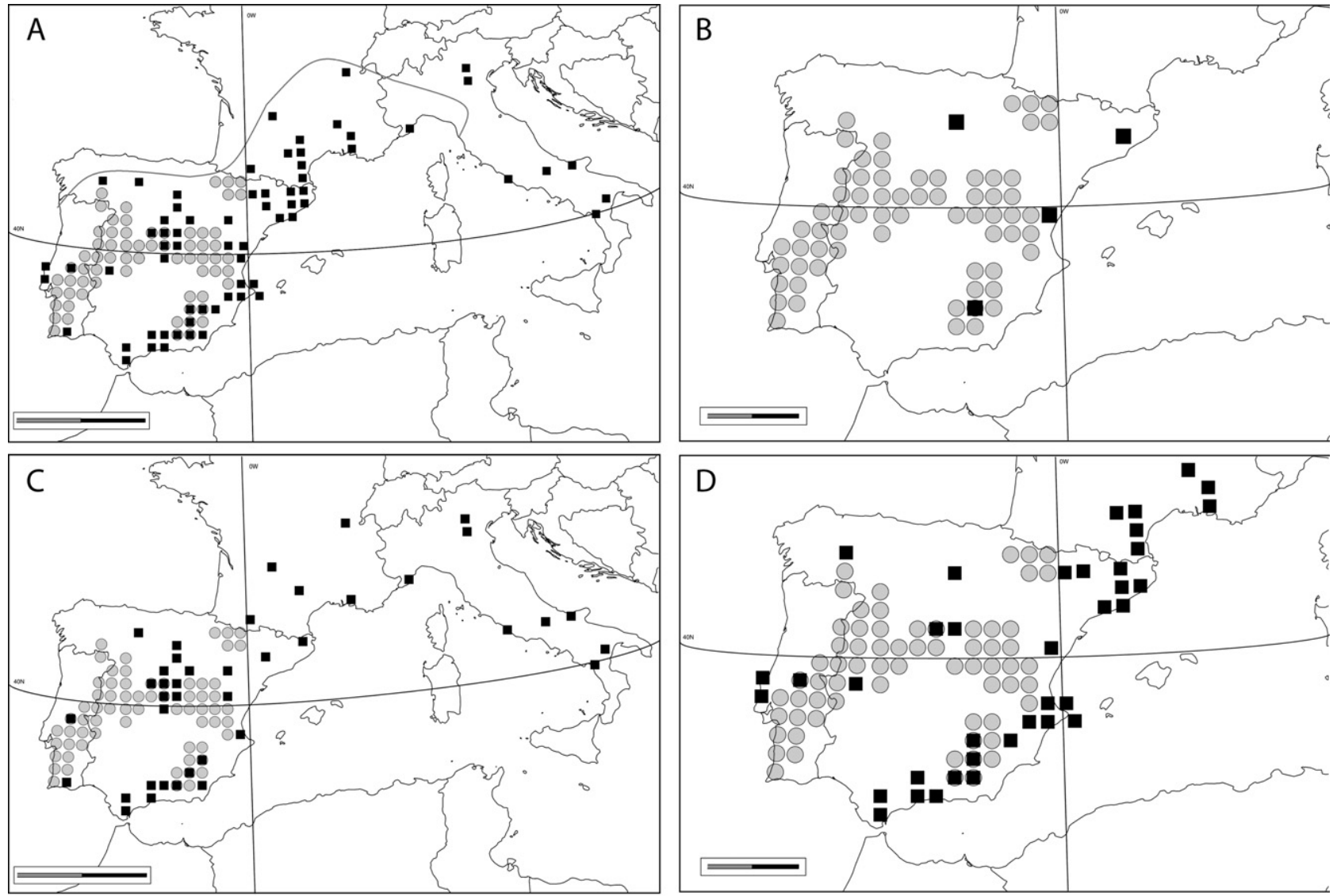

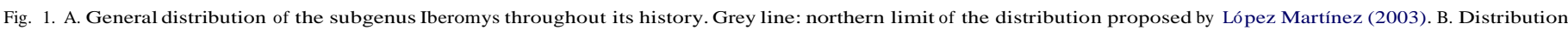

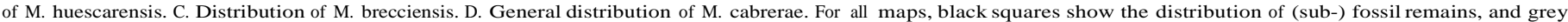
circles show the present-day distribution of M. cabrerae. Scale bars: $500 \mathrm{~km}$ (A, C), $250 \mathrm{~km}$ (B, D).

The remains of the subgenus Iberomys show that it was only found in the Iberian Peninsula, Italy and southern half of France (Fig. 1(A)). Each Iberomys species has occupied at various times different parts of this range. $M$. huescarensis appears as a species endemic to the Iberian Peninsula (Fig. 1(B)); M. brecciensis has the greatest range of the Iberomys species (Fig. 1(C)) and, judging from the distribution of its ancestor, must also be Iberian in origin. Finally, M. cabrerae only appears in the French Mediterranean and the Iberian Peninsula, although in this last region fossil remains have been found in some areas from which it is absent today (western half of the Betic mountains as far as Gibraltar, coast of Valencia, Catalonia, SE France and the east of the Duero Basin; Fig. 1(D)).

On a more detailed scale, M. cabrerae appears as an Iberian endemic in the Upper and Lower Wü rm (Fig. 2(A, B)) and only reaches southern France after the end of the glacial period (Preboreal-Boreal; Fig. 2(C)). From that time onwards, its presence in the Iberian Peninsula has been permanent, whereas in the French Mediterranean region it has only disappeared recently. The most abundant records are from the Atlantic (Asquerino and López, 1981; Alcalde and Brunet-Lecomte, 1985; Sevilla, 1988; Michaux, 1993; Ruiz Bustos, 1995; Guillem Calatayud, 1995, 1999; Martín Colliga, 2000; Guillem Calatayud, 2001; Mistrot, 2001; Pérez-Bote et al., 2003; Vigne, 2003; Arribas, 2004; Sánchez et al., 2005; Baquedano and Laplana, 2006; Oms et al., 2006; López-García, 2008; Callou, 2010; Fig. 2(D)) and Subboreal periods (Alcalde and Brunet-Lecomte, 1985; Guillem Calatayud, 1995, 1999, 2001; Arribas, 2004; López-García, 2008; Jeannet and Vital, 2009; Callou, 2010; Fig. 2(E)). In the Subatlantic period, M. cabrerae is recorded from the SE Iberian Peninsula from post-argaric levels at Cabezo
Gordo (Villena, Alicante province; Morales Muñiz, 1990), SE France (up to Roman times; Vigne, 2003; Callou, 2010), Catalonia (Iron Age; Valenzuela et al., 2009) and the western half of the Betic mountains (sub-fossil remains less than 2000 years old; GarridoGarcía et al., 2010; Fig. 2(F)). Although it has also been indicated from Atlantic-Subboreal levels (Los Millares) in “Almería” (Engels, 1972; Ayarzagüena and López Martínez, 1976; López Martínez, 2003), the only reference for the area obtained during our bibliographical review was from Subatlantic levels from the aforementioned site of Cabezo Gordo.

3.2. Biogeographic centre of origin and characterisation of the taxon cycle in the subgenus Iberomys, and origin of the Holocene process of extinction in M. Cabrerae

The oldest and most primitive fossils of the subgenus Iberomys (M. huescarensis) and of $M$. cabrerae are found in the Iberian Peninsula. Although the evidence is not so clear for $\mathrm{M}$. brecciensis, it is undeniable that if $\mathrm{M}$. huescarensis is an Iberian endemic and his ancestor, then the former could only have first appeared there as well.

On the other hand, Fig. 3 shows that the history of the subgenus Iberomys has undergone an initial phase with a restricted range ( $M$. huescarensis), followed by an important expansion (M. brecciensis) and then the contraction in its range (M. cabrerae). If we centre the analysis on $M$. cabrerae, we observe the same pattern, with an initial phase with a restricted range (Upper and Lower Würm), followed by a maximum expansion (from the Preboreal to the Subboreal) and then a progressive contraction that culminates in the current situation. 

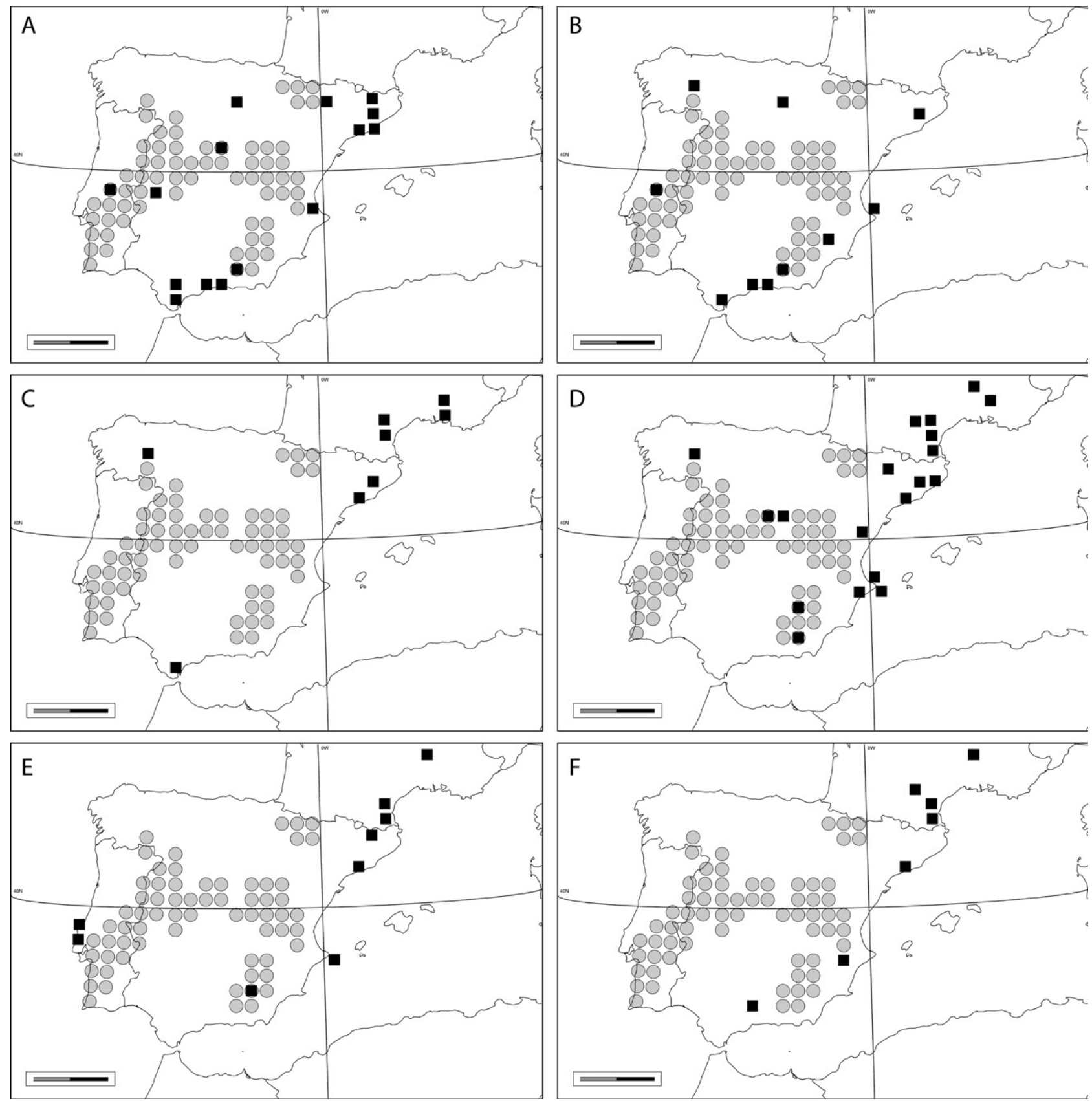

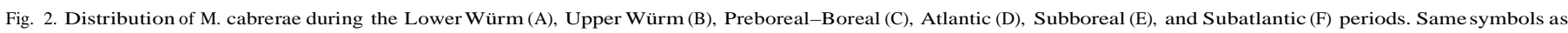
in Fig. 1. Scale bars: $250 \mathrm{~km}$.

This last process started to become apparent at regional scale during the Subatlantic, with the extinction of $M$. cabrerae in Catalonia and the south of France.

\section{Discussion}

4.1. Biogeographical history of $M$. cabrerae and the other species of the subgenus Iberomys

Our results indicate that the subgenus Iberomys should not be considered endemic to the Iberian Peninsula and the Mediterranean coast of France (Ibero-occitan province; Ayarzagüena and López Martínez, 1976; Cabrera-Millet et al., 1983), since its wideranging presence in Italy and France during the Middle Pleistocene means that it is, rather, endemic to the European part of the western Mediterranean. Nevertheless, we should not ignore the importance of the Iberian Peninsula in the evolution of Iberomys, given that all members of this subgenus are found there, and that M. huescarensis and M. cabrerae are both either Iberian or Iberooccitan endemic species. Moreover, the Iberian Peninsula has also acted as a refugium (at least for $\mathrm{M}$. cabrerae during the Upper Pleistocene) and as a departure point for expansions into other areas of western Europe during the Middle Pleistocene (M. brecciensis) and beginning of the Holocene (M. cabrerae). Thus, this group replicates the patterns found in other Iberian taxa that have subsequently become integrated into the biota of the rest of Europe (Taberlet et al., 1998; Gómez and Lundt, 2007).

Beyond these general conclusions, two crucial problems remain to be solved. On the one hand, the expansion of $\mathrm{M}$. brecciensis from the Iberian Peninsula into the rest of Europe supposedly happened 


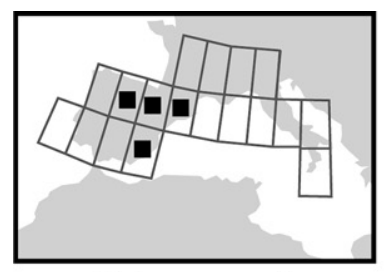

M. huescarensis

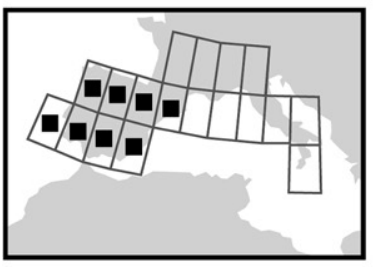

M. cabrerae (Upper Würm)

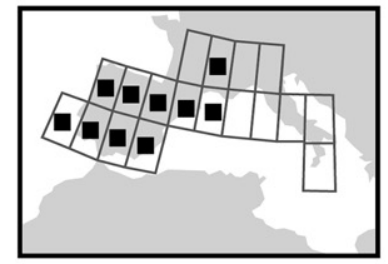

M. cabrerae (Subboreal)

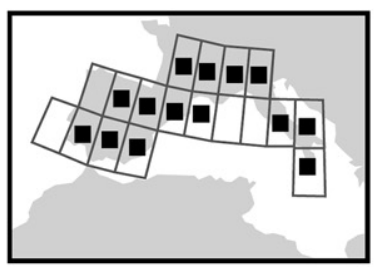

M. brecciensis

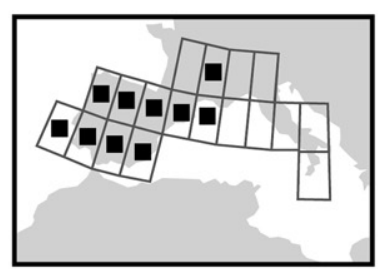

M. cabrerae (Preboreal-Boreal)

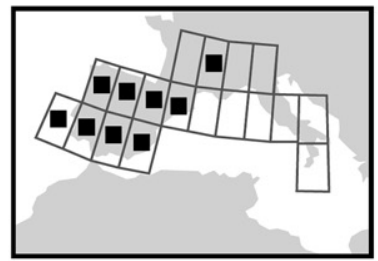

M. cabrerae (Subatlantic)

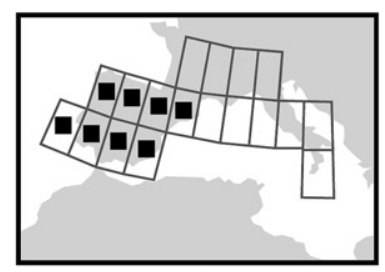

M. cabrerae (Lower Würm)

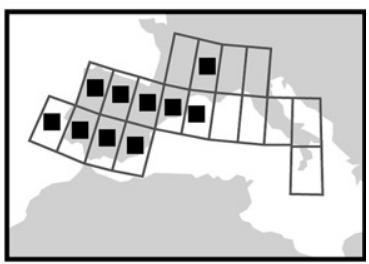

M. cabrerae (Atlantic)

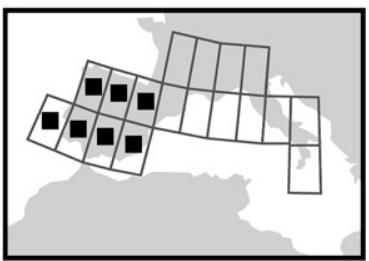

M. cabrerae (Present)

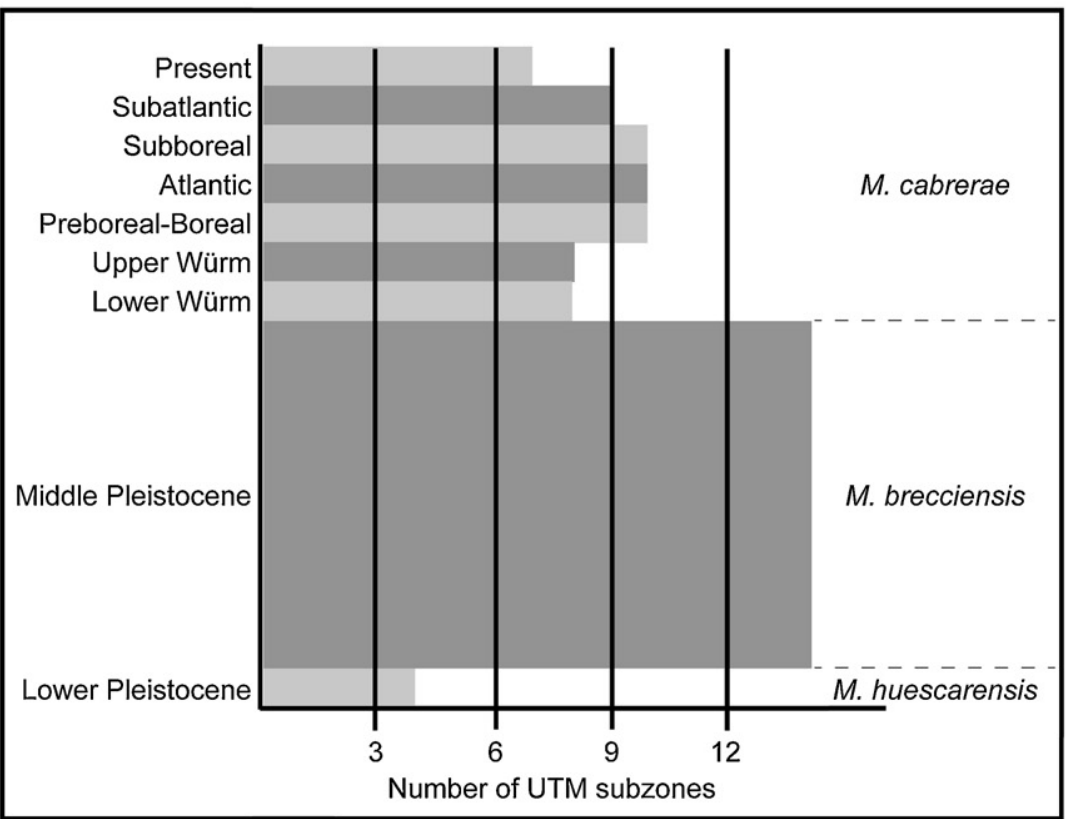

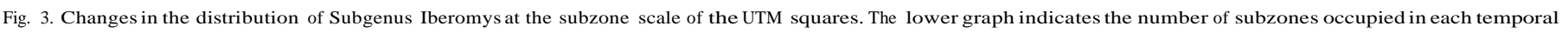
phase.

during the warm humid interglacial periods of the Middle Pleistocene, as occurred in other taxa (Mania, 1995; Cheddadi et al., 1998; Semah and Renault-Miskovsky, 2004). Yet, the mammal communities in central and North-West Europe were very different in each warm period given that they evolved after each glacial period as a result of different faunistic contingents and expansion phenomena originating in the Mediterranean Basin and South-West Asia (Rodríguez, 2006). In such unstable conditions, we do not believe that $\mathrm{M}$. brecciensis would have been able to maintain a constant distribution for the 660,000 years of the Middle Pleistocene. By contrast, this species' range must have undergone contractions in cold periods (as occurred in M. cabrerae during the Wü rm) and (re)colonisations whose extent would have varied in accordance with the capacity of this rodent to integrate itself into the mammal communities present in each interglacial period.

Another problem occurs with M. cabrerae. This species lives in grasslands and rush formations and these habitats cannot survive if average annual temperatures drop below 8 8C (Lorite et al., 2003; Fernández-Salvador, 2007). During the most recent glacial period, the average annual temperatures in the Iberian Peninsula were between 9 and 11 8C lower than at present (Peyron et al., 1998), and so the potential distribution of this vole's habitats may have been severely reduced and fragmented. This would have given rise 
to the appearance of refugia in which allopatric populations of M. cabrerae would have generated a complex phylogeographic structure with crypto-taxa that have not been detected by anatomical studies (Ayarzagüena and López Martínez, 1976). These phenomena have occurred in other Iberian taxons (Gómez and Lundt, 2007).

Both questions could be further analysed by means of a more intensive and detailed study of the spatio-temporal distribution of the subgenus Iberomys fossil record during the Middle and Upper Pleistocene and, in the case of $\mathrm{M}$. cabrerae, by means of a determination of the phylogeographic structure of current populations that would enable us to situate this species' refugia during the Wü rm.

\subsection{Location of the biogeographic centre of origin and}

characterisation of taxon cycle in the subgenus Iberomys

López Martínez (2003, 2009) indicates that:

- It is only possible to determine the place of origin of taxa to a very imprecise level (to that of a continent or an ocean);

- The expansion of new taxa occurs much more quickly and unpredictably than extinction processes.

Thus, this author rejects the validity of the Symmetrical Model as a description of a "taxon cycle" (that is, an initially limited distribution associated with its centre of origin, followed by an expansion that continues until its whole ecological niche has been occupied, and then by a contraction that ends in extinction) and proposes an Asymmetrical Model (the taxon would reach its maximum expansion from its origin). To support this theory this author cites the subgenus Iberomys as an example and describes the evolution of its distribution area in three successive phases: M. brecciensis, which appears almost simultaneously in the Iberian Peninsula, France and north-west Italy ("1 MA ago"), M. cabrerae, which as an Ibero-occitan endemic species that appeared "6000 years ago"' and, finally, the current situation of this taxon, disjoint and restricted to the Iberian Peninsula, in what is a mere prelude to its extinction.

Our results demonstrate that, actually, the history of the subgenus Iberomys and M. cabrerae fits the Symmetrical Model more closely, with an initial phase with a restricted range followed by an expansion and then a later contraction in its range. Moreover, if we take the oldest and most primitive fossils as indications of the centre of origin of a taxon (López Martínez, 2003), the centres of origin of the subgenus Iberomys and $\mathrm{M}$. cabrerae are located in the Iberian Peninsula. The use of the subgenus Iberomys to support the hypothesis of the lack of definition of the centre of origin and the Asymmetrical Model is thus erroneous since its analytic base (Ayarzagüena and López Martínez, 1976; Cabrera-Millet et al., 1983) has been rendered obsolete after the great advances made in the knowledge of the fossil record in the last three decades.

\subsection{The origin of the conservation problems in M. cabrerae}

The transition between the Atlantic and Subboreal periods is the key period in the environmental history of the Holocene. At a world-wide level, this period is characterized by the beginning of a colder and drier climate than during the Atlantic period, and in the western Mediterranean Basin there was an expansion of semi-arid steppes and pine and evergreen oak forests to the detriment of the deciduous oak/holly formation that had dominated the landscape until then (Borzenkova, 1990; Carrión et al., 2007). Nevertheless, it is not clear whether this change in the dominant plant communities was due to the more arid climate, to the intensification of human activity that caused a diverse response from tree species whereby those better adapted to summer drought and poor soils were favoured, or a combination of both factors (Quézel and Médail, 2003; Carrión et al., 2007). The same problem appears when trying to determine the origin of changes detected in the mammal fauna, the conclusion being that it is very difficult to differentiate processes of anthropic origin from those determined by climate changes (Garrido-García, 2008).

López Martínez (2003) suggested that the reduction in the range of M. cabrerae during the Holocene was due to the Subboreal climatic crisis, and considered as a proof the fact that the extinct populations of this rodent in the South-East of the Iberian Peninsula lie outside the current bioclimatic niche of this rodent (Jijona, Alicante and Almería in Fig. 2(C)), but ignored the fact that most of the extinct populations that also appear on the map (Draguignan, Montpellier, Carpentras, Marseille, Aix, Campo Mayor, Beja) were subject to current climate conditions similar to present-day populations. Therefore, they did not live in areas that currently are climatically unsuitable for the species. Our results show that, moreover, its area of distribution at regional scale did not shrink in parallel with the climatic crisis; rather, populations retracted much later and were intact almost constantly until the Subatlantic period (Fig. 3).

To understand the effect that this climatic crisis could have had on M. cabrerae, it is essential to make a finer analysis of its ecological requirements. As in the other Microtinae, its diet is based on grass stems and leaves (Soriguer and Amat, 1988). In the Mediterranean, characterised by an intense summer drought, herbaceous plants are only a seasonal resource and the few Microtinae that live in these environments have had to adapt and exploit trophic resources that survive during this period of scarcity (Orsini and Poitevin, 1984). Thus, M. cabrerae has become an edapho-hygrophilous species that depends on habitats such as permanent grassland and rush communities growing on soils with high groundwater levels, which in most cases are fed by subterranean aquifers (Soriguer et al., 2003; Fernández-Salvador, 2007; Rosário et al., 2008). These hydrogeological formations are very resilient to climate change as the persistence for millennia of fossil aquifers in the Sahara desert shows (Edmunds and Wright, 1979). Thus, it is unlikely that the increasingly arid climate during the Subboreal- less intense in the Iberian Peninsula than in the Sahara (Borzenkova, 1990) - would have had the necessary intensity to completely eliminate aquifers and damp grasslands and rush formations at a regional scale.

All these reasons lead us to rule out the possibility that the reduction and fragmentation of the distribution of $\mathrm{M}$. cabrerae in the Upper Holocene could be related to the Subboreal climatic crisis; instead, this loss can probably be attributed to the expansion of agriculture, which remains one of the principal problems facing the species (Fernández-Salvador, 2007). During the Subboreal period, the first irrigation systems were developed in the Iberian Peninsula (Díaz Hernández et al., 2000). This led to a ploughing up of valley bottoms, which reached its maximum intensity in the Middle Age (Bertrand and Sánchez Viciana, 2006) and surely resulted in the destruction of many appropriate habitats for this rodent. According to our proposal, much of the reduction and fragmentation of the distribution area of $\mathrm{M}$. cabrerae has been caused by human activity and not by climatic changes. Therefore, it is possible to prevent further extinctions of populations through conservation and management measures. This is the basis of the strategy developed by our research group in Andalusia (southern Spain), with financial support from the regional government.

\section{Acknowledgements}

We are very grateful to C. Callou (Inventaire national du Patrimoine naturel/MNHN-Paris) for the data provided on 
M. cabrerae from French archaeological deposits. We thank Gloria Cuenca-Bescós (University of Zaragoza) and the reviewers of the manuscript (M.C. Sesé and A. Nadachowski) for their valuable comments on the original version of this article.

\section{Appendix A. Supplementary data}

Supplementary data associated with this article can be found, in the online version, at http://dx.doi.org/10.1016/j.geobios.2011. 10.014 .

\section{References}

Alcalde, G., Brunet-Lecomte, P., 1985. Contribució al coneixement del medi i el clima durant el Plesitocè superior i l'holocè a Catalunya, amb l'aplicació de l'ànalisis factorial de correspondencies a les associacions de rosegadors. Paleontología y Evolució 19, 49-55.

Alves, P.C., Barroso, I., Beja, P., Fernandes, M., Freitas, L., Mathias, M.L., Mira, A., Palmeirim, J., Prieto, R., Rainho, A., Santos-Reis, M., Sequeira, M., Rodrigues, L., 2006. Microtus cabrerae Thomas, 1906. Rato de Cabrera. In: Raposo de Almeida, P., Almeida, J., Ferrand de Almeida, N., Cabral, M.J., Dellinger, T., Oliveira, M.E., Palmeirim, J., Queiroz, A.I., Rogado, L., Santos-Reis, M. (Eds.), Livro Vermelho dos vertebrados de Portugal. Revisao.ICPN, Lisboa, pp. 481-482.

Arribas, O., 2004. Fauna y paisaje de los Pirineos en la Era Glaciar. Territori i Paisatge. Edición Lynx, Barcelona.

Asquerino, M.D., López, P., 1981. La cueva del Nacimiento (Pontones): un yacimiento neolítico en la Sierra de Segura. Trabajos de Prehistoria 38, 109-148.

Ayarzagüena, J., López Martínez, N., 1976. Estudio filogenético y comparativo de Microtus cabrerae y Microtus brecciensis. Doñana Acta Vertebrata 3, 181-204.

Baquedano, E., Laplana, C., 2006. The Pinilla del Valle (Lozoya Valley Madrid) Paleontological sites (Late Pleistocene). In: Cuenca-Bescós, G. (Ed.), Guía de la Excursión EuroMan. Workshop, Zaragoza, pp. 1-5.

Bertrand, M., Sánchez Viciana, J.R., 2006. L'irrigation du territoire de Guadix, les grandes acequias de Sierra Nevada: l’Acequia de la Sierra. In: Cressier, P. (Ed.), La maîtrise de l'eau en Al-Andalus. Paysages, pratiques et techniques. Casa de Velazquez, Madrid, pp. 1-49.

Blondel, J., Aronson, J., 1999. Biology and wildlife of the Mediterranean Region. Oxford University Press, Oxford.

Bon, M., Piccoli, G., Sala, B., 1991. I giacimenti Quaternari di vertebrati fossili nell'Italia Nord-Orientale. Memorie degli Instituti di Geologia e Mineralogia dell'Universita di Padova 47, 185-231.

Borzenkova, I.I., 1990. Climatic changes through late glacial and postglacial 16-0 ka BP. In: Zubakov, V.A., Borzenkova, I.I. (Eds.), Global paleoclimate of the late Cenozoic. Elsevier, New York, pp. 251-295.

Bullejos, M., Sánchez, A., Burgos, M., Hera, C., Jiménez, R., Díaz de la Guardia, R., 1997. Multiple, polymorphic copies of SRY in both males and females of the vole Microtus cabrerae. Cytogenetic and cell genetics 79, 167-171.

Cabrera-Millet, M., López, N., Michaux, J., 1983. Un exemple de lignée endémique iberoccitane, les campagnols Microtus brecciensis et Microtus cabrerae (Mammalia, Rodentia): étude phylogénétique et contexte écologique d'un phénomène évolutif récent. In: Buffetaut, E., Mazin, J.M., Salmon, E. (Eds.), Actes du Symposium Paléontologique Georges Cuvier. Montbéliard, pp. 69-83.

Callou, C., 2010. Microtus cabrerae. Inventaire archéozoologique et archéobotanique de France (Inventaire national du patrimoine naturel). Muséum national d'Histoire naturelle, Paris (unpublished).

Carrión, J.S., Fuentes, N., González-Sampériz, P., Sánchez Quirante, L., Carrión, J.C., Finlayson, J.C., Fernández, S., Andrade, A., 2007. Holocene environmental change in a montane region of southern Europe with a long history of human settlement. Quaternary Science Reviews 26, 1455-1475.

Chaline, J., 1974. Palingenèse et phylogenèse chez les Campagnols. Comptes Rendus de l'Académie des Sciences de Paris D 278, 437-440.

Cheddadi, R., Mamakowa, K., Guiot, J., Beaulieu, J.L., Reille, M., Andrieu, V., Granoszewski, W., Peyron, O., 1998. Was the climate of the Eemian stable?. A quantitative climate reconstruction from seven European pollen records. Palaeogeography Palaeoclimatology Palaeoecology 143, 73-85.

Cuenca-Bescós, G., Rofes, J., López-García, J.M., Blain, H.A., de Marfá, R.J., GalindoPellicena, M.A., Bennásar-Serra, M.L., Melero-Rubio, M., Arsuaga, J.L., Bermúdez de Castro, J.M., Carbonell, E., 2010. Biochronology of Spanish Quaternary small vertebrate faunas. Quaternary International 212, 109-119.

Delgado Castilla, L., Pascual Molina, A., Ruiz Bustos, A., 1993. Geology and micromammals of the Serra-1 site (Tabernas Basin Betic Cordillera). Estudios Geoló gicos 49, 361-366.

Dennell, R., 1999. Prehistoria económica de Europa. Crítica, Barcelona.

Díaz Hernández, J.L., Martín, M., Juliá, R., 2000. Depósitos travertínicos de Alicún (Depresión de Guadix, Granada S. de España). Geogaceta 28, 35-38.

Edmunds, W.M., Wright, P.E., 1979. Groundwater recharge and palaeoclimate in the Sirte and Kufra basins. Journal of Hydrology 40, 215-241.

Engels, H., 1972. Kleinsaüger aus Portugal. Bonn Zoological Beitrage 21, 89-118.

Fernandes, M., Pita, R., Mira, A., 2008. Microtus cabrerae. In: IUCN (Ed.), IUCN Red List of Threatened Species. Version 2009.1 [www.iucnredlist.org, downloaded on September, 08, 2009].
Fernández-Salvador, R., 2007. Microtus cabrerae Thomas, 1906, Topillo de Cabrera. In: Palomo, J.L., Gisbert, J., Blanco, J.C. (Eds.), Atlas y Libro Rojo de los mamíferos terrestres de España. DGCNA/TRAGSA/SECEM/SECEMU, Madrid, pp. 429-433.

Fernández-Salvador, R., García-Perea, R., Ventura, J., 2001. Reproduction and postnatal growth of Cabrera vole, Microtus cabrerae, in captivity. Canadian Journal of Zoology 79, 2080-2085.

Garrido-García, J.A., 2008. Las comunidades de mamíferos del sureste de la Península Ibérica: elementos para un análisis histórico. Galemys 20, 3-46.

Garrido-García, J.A., Soriguer, R.C., Pérez-Aranda Serrano, D., Pardávila, X., 2008. A revision of the distribution of Cabrera's vole (Microtus cabrerae Thomas, 1906) in Andalucía (Southern Spain). Hystrix (n. s.) 19, 41-51.

Garrido-García, J.A., Triano-Muñó z, E., Soriguer, R.C., 2010. Revisión del estatus del topillo de Cabrera Microtus cabrerae Thomas, 1906 y la rata de agua Arvicola sapidus Miller, 1908 en las sierras subbéticas cordobesas (Andalucía). Galemys 22, 21-27.

Giebel, C.G., 1874. Fauna der Vorwelt mit steter Berücksichtigung der lebenden Thiere, 1. Vögel und Amphibien, Brockhaus, Leipzig.

Gómez, A., Lundt, D.H., 2007. Refugia within Refugia: patterns of phylogeographic concordance in the Iberian Peninsula. In: Weiss, S., Ferrand, N. (Eds.), Phylogeography in Southern European Refugia: evolutionary perspectives on the origins and conservation of European biodiversity. Kluwer Academic Press, New York, pp. 155-188.

Guillem Calatayud, P.M., 1995. Paleontología continental: microfauna. In: V.V.A.A (Eds.), El Cuaternario del País Valenciano. Universidad de Valencia, Valencia, pp. 227-233.

Guillem Calatayud, P.M., 1999. Los micromamíferos (Rodentia, Insectivora y Chiroptera) de la secuencia holocena de la Cova de Cendres y Cova de Bolumini. Saguntum PLAV. Spec. Num. 1999, 31-36.

Guillem Calatayud, P.M., 2001. Los micromamíferos y la secuencia climática del Pleistoceno Medio Pleistoceno Superior y Holoceno, en la fachada central mediterránea. In: Villaverde, V. (Ed.), De Neandertales a Cromañones. El inicio del poblamiento humano en las tierras valencianas. Universidad de Valencia, Valencia, pp. 57-72.

Jaarola, M., Martinkova, N., Gündüz, I., Brunhoff, C., Zima, J., Nadachowski, A., Amori, J., Bulatova, N.S., Chondropoulos, B., Fraguedakis-Tsolis, S., González-Esteban, J., López-Fuster, M.J., Kandaurov, A.S., Kefelioglu, H., Mathias, M.L., Villate, I., Searle, J.B., 2004. Molecular phylogeny of the species of voles of the genus Microtus (Arvicolinae Rodentia) inferred from mitochondrial DNA sequences. Molecular Phylogenetics and Evolution 33, 647-663.

Jeannet, M., Vital, J., 2009. La grotte de la Chauve-Souris à Donzère (Drôme, France). L'environnement holocène par la méthode quantitative appliquée aux microvertébrés. Essai de définition et application. Revue de Paléobiologie 28, 139-173.

Laplana, C., Cuenca-Bescós, G., 1998. Precisiones sobre la sistemática de subgenus Iberomys Chaline, 1972 (Arvicolidae, Rodentia Mammalia) del Pleistoceno inferior de la Sierra de Atapuerca (Burgos, España). Geogaceta 24, 183-186.

López-García, J.M., 2008. Evolución de la diversidad taxonómica de los micromamíferos en la Península Ibérica y cambios paleoambientales durante el Pleistoceno Superior. Ph.D. Thesis, Universidad Rovira i Virgili, Barcelona (unpublished).

López Martínez, N., 2003. La búsqueda del centro de origen en biogeografía histórica. Graellsia 59, 503-522.

López Martínez, N., 2009. Time asymmetry in the paleobiogeography history of species. Bulletin de la Société géologique de France 180 (1), 45-55.

Lorite, J., Valle, F., Salazar, C., 2003. Síntesis de la vegetación edafohigrófila del Parque Natural y Parque Nacional de Sierra Nevada. Monografías de Flora y Vegetación Béticas 13, 47-110.

Mania, D., 1995. The influence of quaternary climatic development on the Central European mollusc fauna. Acta Zoologica Cracoviensia 38, 17-34.

Martín Colliga, A., 2000. Els primers pastors de Sant Llorenç del Munt al IV millenn aC. Servei d'Arqueología de la Generalitat de Catalunya. Monografies 29, 197-204.

Mazo, A.V., Sesé, C., Ruiz Bustos, A., Peña, J.A., 1985. Geología y Paleontología de los yacimientos Plio-Pleistocenos de Huéscar (Depresión de Guadix-Baza, Granada). Estudios Geológicos 41, 467-493.

Michaux, J., 1993. Liste de Rongeurs. In: Paccard, J. (Ed.), La grotte d'Unang à Malemort du Comtat. Services Départementaux de l'Archéologie, Avignon, pp. 145-146.

Miller, G.S., 1910. Description of six new European mammals. Annals and magazine of natural history, series $810,459-461$.

Ministerio de Defensa, 1997. Mapa Militar Digital de España v. 1.5. Escala 1:250000 y 1:800000. CD Software. Ministerio de Defensa, Madrid.

Mistrot, V., 2001. Contribution des micromammifères de la Balma de l'Abeurador à la connaissance de l'évolution des paysages tardiglaciaires et holocènes en Languedoc-Roussillon. Mémoire de Doctorat de l'Université Panthéon-Sorbonne-Paris I (unpublished).

Mitchell-Jones, A.J., Amori, G., Bogdanowicz, W., Krystufek, B., Reijnders, P.J.H., Spitzenberger, F., Stubbe, M., Thissen, J.B.M., Vohralik, V., Zima, J., 1999. The Atlas of European mammals. T\&AD Poyser, London.

Montes Ramírez, L., 2007. El Epipaleolítico reciente o mesolítico en la Península Ibérica. Estado de la cuestión. Caesaragustana 78, 39-48.

Morales Muñiz, A., 1990. Arqueozoología teórica: usos y abusos reflejados en la interpretación de las asociaciones de fauna de yacimientos antrópicos. Trabajos de Prehistoria 47, 251-290.

Oms, X., Bargalló, A., Chaler, M., Fonatanals, M., García, M.S., López-García, J.M., Morales, J.I., Nievas, T., Rodríguez, A., Serra, J., Solé, A., Vergès, J.M., 2006. La 
Cova Colomera (Sant Esteve de la Sarga, Lleida), una cueva-redil en el prepirineo de Lérida, primeros resultados y perspectivas de futuro. In: Hernández Pérez, M.S., Soler Díaz, J.A., López, Padilla, J.A. (Eds.), Actas IV Congreso de Neolítico Peninsular. Alicante 1, pp. 230-236.

Orsini, P., Poitevin, F., 1984. Essai de caractérisation de la Region Méditerranéenne française à partir du régime alimentaire de la chouette effraie (Tyto alba). Rapinyaires Mediterranis II, 221-228.

Otte, M., 2002. La protohistoire. De Boeck Université, Bruxelles.

Pascal, M., Lorvelec, O., Vigne, J.D., 2006. Invasions biologiques et extinctions. 11000 ans d'histoire des vertébrés en France. Belin, Paris.

Pérez-Bote, J.L., Roso, R., Romero, A.J., Perianes, M., López, M.T., 2003. Nuevos datos sobre el Neolítico en el Maestrazgo: el Abric del Mas de Martí (Albocàsser, Castelló). In: Ontañón Peredo, R., García-Moncó Piñeiro, C., Arias Cabal, P. (Eds.), Actas del III Congreso del Neolítico en la Península Ibérica. Santander, pp. 879-887.

Peyron, O., Guiot, J., Cheddadi, R., Tarasov, P., Reille, M., Beaulieu, J.L., Bottema, S., Andrieu, V., 1998. Climatic reconstruction in Europe for 18000 yr BP from pollen data. Quaternary Research 49, 183-196.

Quézel, P., Médail, P., 2003. Écologie et biogéographie des forêts du bassin méditerranéen. Elsevier, Paris.

Riser, J., 1999. Le Quaternaire. Géologie et milieux naturels. Dunod, Paris.

Rodríguez, J., 2006. Structural continuity and multiple alternative stable states in Middle Pleistocene European mammalian communities. Palaeogeography Palaeoclimatology Palaeoecology 239, 355-373.

Rosário, I.T., Cardoso, P.E., Mathias, M.L., 2008. Is habitat selection by the Cabrera vole (Microtus cabrerae) related to food preferences? Mammalian Zoology 73, 423-429.

Ruiz Bustos, A., 1995. Biostratigraphy of the continental deposits in the Granada. Guadix and Baza basins (Betic Cordillera). In: Gibert, J., Sánchez, F., Gubert L., Robot, F. (Eds.), Los Homínidos y su entorno en el Pleistoceno inferior y medio de Eurasia. Actas del Congreso Internacional de Paleontología Humana. Orce, pp. 153-171.

Ruiz Bustos, A., 2000. Estudio paleoecológico de los sedimentos con presencia de Hombre de Neandertal en la Cueva de la Carihuela (Piñar, Granada). Síntesis ambiental del Würm mediterráneo en la Cordillera Bética. Ayto de Píñar, Píñar.

Sánchez, A., Fraile, S., Van der Made, J., Morales, J., Quiralte, V., Salesa, M.J., Sánchez, I.M., Sanchíz, B., Soria, D., Jiménez, J., Barbadillo, L.J., Laplana, C., Szyndlar, Z.
2005. Primeros datos faunísticos del Neolítico madrileño: la cueva de La Ventana (Torrelaguna, Madrid). In: Arias Cabal, P., Ontañón Peredo, R., García-Moncó Piñeiro, C. (Eds.), Actas del III Congreso del Neolítico de la Península Ibérica. Santander, pp. 155-165.

Semah, A.M., Renault-Miskovsky, J., 2004. L'évolution de la végétation depuis deux millions d'années. Artcom-Errance, Paris.

Sevilla, P., 1988. Estudio paleontológico de los Quirópteros del Cuaternario Español. Paleontología i Evolució 22, 113-233.

Sommer, R., Benecke, N., 2004. Late- and Post-Glacial history of the Mustelidae in Europe. Mammal Review 34, 249-284.

Sommer, R., Benecke, N., 2005. Late Pleistocene and early Holocene history of the canid fauna of Europe (Canidae). Mammalian Biology 70, 227-241.

Sommer, R., Benecke, N., 2008. Late Pleistocene and Holocene development of the felid fauna (Felidae) of Europe: a review. Journal of Zoology 269, 7-19.

Soriguer, R.C., Amat, J.A., 1988. Feeding of Cabrera vole in west-central Spain. Acta Theriologica 33, 589-593.

Soriguer, R.C., Carro, F., Márquez, F.J., Fandos, P., 2003. Diversidad y abundancia de los micromamíferos ibéricos. In: Perez Jiménez, J. (Ed.), Memoriam al Profesor Dr. Isidoro Ruiz Martínez. Jaén, pp. 439-478.

Taberlet, P., Fumigalli, L., Wust-Saucy, A.G., Cossons, F.J., 1998. Comparative phylogeography and postglacial colonization routes in Europe. Molecular Ecology 7, 453-463.

Valenzuela, S., Poitevin, F., Cornette, R., Bournery, A., Nadal, J., Vigne, J.D., 2009. Evolving ecosystems: ecological data from an Iron Age small mammal accumulation at Alorda Park (Catalonia, Spain). Journal of Archaeological Science 36, 1248-1255.

Ventura, J., López-Fuster, M.J., Cabrera-Millet, M., 1998. The Cabrera vole, Microtus cabrerae, in Spain: a biological morphometrical approach. Netherland Journal of Zoology 47, 1-18.

Vernet, J.L., 1997. L’homme et la forêt méditerranéenne de la Préhistoire à nos jours. Errance, Paris.

Vigne, J.D., 2003. Le campagnol méditerrané: Microtus cabrerae Thomas, 1906. In: Pascal, M., Lorvelec, O., Vigne, J.D., Clergeau, P. (Eds.), Évolution holocène de la faune de Vertébrés de France: invasions et extinctions. Rapport pour le Ministère de l'Écologie et du Développement Durable (Dir. de la Nature et des Paysages). Version définitive du 10 juillet 2003. INRA/CNRS/MNHN-Paris, Paris, pp. 100-101. 